\title{
REPORTS AND CORRESPONDENCE
}

\section{Bridging the Gap: New York State Labor History Conference on Women, Work, and Community}

\author{
Sue Cobble \\ Rutgers University
}

Our concerns as historians of the working-class are undeniably influenced by the dilemmas confronting activists in the 1980s. At heart we remain committed to a history which will illuminate the present as well as the past. The New York State Labor History Association (NYSLHA), founded in 1976, declares this notion of scholarship explicitly. Its activities, ranging from the "labor news service," which prepares monthly labor history articles for union subscribers to their annual conference on issues of "historical and current concern," are ambitious attempts to bridge the gap "between past and present, between unionists and academics."

The association's conference on "Women, Work and Community," held February 27, 1987, at New York University, brought together union leaders and staff, rank-and-file activists (many paid for by their New York City locals), labor educators, archivists, historians, sociologists, and other researchers. The nearly two hundred participants were treated to informed and even elegant presentations, and lively debate sprang up at every opportunity.

The conference also confirmed that the chasms we seek to cross are wide. Many of the historical presentations were infused with present-day concerns, but few speakers from either the audience or the panels applied the lessons of history to solving the problems of the present. The present informed historical endeavors but not vice versa: the traffic on the bridge between past and present flowed but one way.

As the conference coordinator and vice-president of the NYSLHA, Lee Levin of the Coalition of Labor Union Women (CLUW) opened the conference by linking the fates of organized labor and working women: economic justice for working women cannot be achieved without a strong labor movement, yet the future of that labor movement depends on the actions and attitudes of women. Michael Donovan, president of NYSLHA, then introduced Alice Kessler-Harris (Hofstra), who offered a stirring, incisive keynote address. Appealing to both academics and activists, Kessler-Harris relied on historical an- 
ecdotes to reinforce her insights concerning present-day policy toward women and the family. Kessler-Harris argued that as historians and as social-policy analysts, we must move beyond "universal conceptions" of women and pay attention to class and race differences. Although "universal notions of difference" have been used against women historically, recognizing differences among women as well as between men and women is imperative in formulating policy that will truly represent the interests of all women.

Rochelle Semel, director of the Labor Liberal Arts Program at Cornell's School of Industrial and Labor Relations, presented a second keynote during lunch. Semel recounted the impressive growth of labor programs for union women in the New York area and the crucial role these programs have played in moving women into trade union leadership. In part because of programs such as Trade Union Women's Studies, "working women are shaking up the labor movement."

Conference planners organized the bulk of the day around panels, each consisting of a chair and three or four speakers. One speaker on each panel provided a "scholarly perspective"; the other panelists drew on their current experiences as activists and union leaders. The potential for creative give and take existed, and in many cases sparks began to fly. The level of interaction would have been heightened, however, had the panel moderators taken a more active role in synthesizing the divergent perspectives of panelists and had there been more time for audience discussion.

The morning panel on "Women's Leadership in the Labor Movement" combined the personal insights of two generations of women labor officials with sociologist Diane Harriford's analysis of the New York City CLUW chapter. Primarily a black organization by 1980 , NYC CLUW achieved considerable power using the sophisticated tactics black women had learned through their church and community groups. Harriford prophesied that increasingly the labor and women's movement will rely on the energy and commitment of black women.

The two veteran labor leaders on the panel, Ida Torres, secretary-treasurer of the United Storeworkers, Local 3, and Clara Allen, assistant to the vicepresident, Region 1, Communication Workers of America (CWA), demonstrated in form and content who succeeds in the union movement and how. Laura Unger, an of ficer of CWA Local 1150 and a more recent addition to the ranks of labor leadership, explained that it would be easy for women leaders to be just as underpaid, stressed, and "banquet-glutted" as male officials, but why seek that? "Women who strive to be equal to men lack ambition,"' Unger quipped. She didn't seek "to be just a little bit better of a bureaucrat" but to transform the labor movement. Her advice included emphasizing the need for "an independent political voice" and the formation of alliances with community groups, the unemployed, and other disenfranchised groups. Although a stimulating discussion ensued, the critical question of whether women moving 
into positions of power will actually make any difference in the fortunes of the U.S. labor movement remained unaddressed.

Two afternoon panels rounded out the conference. In introducing the panel on "Community and Family," Robert Wechsler of the Transport Workers Union noted that the unions surviving in the 1980s are those rooted in the community and family needs of their members. The experiences recounted by Lisa May, director of the Family and Work Project for Local 8-149 of the Oil, Chemical and Atomic Workers Union, and Katie Quan, organizer for Local 89-22-1 of the International Ladies Garment Workers Union (ILGWU) confirmed his perception. Their locals had been recharged through the energy of rank-and-file workers, primarily women, who had taken up issues extending beyond the workplace. In May's case, the union set up a Work and Family Committee to deal with the problems work creates for family life. Katie Quan and other Chinese garment workers initiated a drive for day-care services that ultimately resulted in the first community-based, union-sponsored day-care center in New York. The campaign also transformed the women in the local as they organized petition drives, set up press conferences, and negotiated with politicians, union officials, and employers.

Audience reaction following this panel, however, centered on Altagracia Ortiz's account of the ILGWU and its treatment of Puerto Rican women workers. Ortiz, a history faculty member at John Jay College in New York, argued that the ILGWU discriminated against Puerto Rican women in denying them training opportunities, union leadership positions, and equal working conditions in the shop. Members in the audience defended the ILGWU as a union open to immigrant groups and contended that the problems experienced by Puerto Rican women cannot be explained primarily as a product of a prejudiced leadership.

The last panel of the conference focused on historical and contemporary strategies to rectify wage discrimination. Drawing on my research on waitress unions and other sources, I discussed the changing approaches pursued by working women in the twentieth century. Union women supported the concept of equal pay and put forth sophisticated arguments as to the justice of the idea, but they opposed the actual implementation of equal-pay contract clauses and legislative proposals until the late 1930s. In the postwar era, however, women unionists emerged as leaders in the fight for equal pay, pushing for contract protections and for broadly defined legislation on the state and federal level. They argued for a "fair rate for the job irrespective of the sex of the worker," thus anticipating many of the comparable worth arguments of the 1980s.

Betsy Wade, former president, Newspaper Guild Local 3, and Ida Torres of the United Storeworkers, Local 3 detailed specific approaches adopted by their unions in countering wage discrimination. The Storeworkers negotiated an antidiscrimination clause as early as 1937 , but in the 1970 s found that wom- 
en were still paid a straight wage while men received the high-wage commission jobs. They renegotiated their payment systems in 1974, breaking down many of the sex-linked categories. The Newspaper Guild also took action in the 1970s: the national bargaining team systematically "desexed" job titles and set up programs to dismantle occupational ghettos.

The concluding discussion began with questions to the panelists but quickly moved into an open exchange on the crisis in bargaining and how unionists can maintain the gains of the past. A handful of participants were interested in devising goals for the future, but the majority needed weapons that would help them survive the present.

After the conference's conclusion, many in the audience settled into animated conversations concerning day-to-day battle strategies and tactics. Perhaps, had time been set aside earlier for this kind of interaction, the difficult pursuit of historical lessons would have emerged in a more focused fashion toward the end. Yet clearly, the thoughtful presentations, forthright debates, and the presence of so many engaged activists energized those present and created a sense of optimism that lasted well beyond the conference.

Those responsible for this innovative, energetic conference, including Miriam Frank, Lee Levin, and other NYSLHA officers, deserve praise. Their careful planning and good judgment were evident throughout. They brought together women from varying class, racial, and ethnic backgrounds, and they valued the voices of working women themselves, not just the writings about them pouring forth from the universities. The conference was a model in its recognition that real solutions to the problems facing working women must emerge from diversity and from practical as well as theoretical understandings.

As for our bridge-building project, I am convinced that the gap between academics and activists will be closed only when it is breached in individual lives. To the extent that the conference encouraged individuals to combine practice and preaching, it was a success. The answer lies in acting together as well as attending conferences together. 